Review Article

\title{
Spinal Extraosseous Extradural Ewing's Sarcoma: A Systematic Review
}

\author{
Kashif Ali Sultan ${ }^{1}$, Biah Mustafaㄹ, Mohammad Ashraf ${ }^{3}$, Minaam Farooq $^{2}$, Naveed Ashraf', $^{1}$ \\ Mukarram Farooq ${ }^{4}$, Musa Ali Rizvi ${ }^{2}$, Waaiz Ali Wajid ${ }^{2}$ \\ ${ }^{1}$ Department of Neurosurgery, Jinnah Hospital, Lahore, Pakistan. \\ ${ }^{2}$ King Edward Medical University (KEMU), Lahore, Pakistan \\ ${ }^{3}$ University of Glasgow, Wolfson School of Medicine, United Kingdom. \\ ${ }^{4}$ Allama Iqbal Medical College (AIMC), Lahore, Pakistan.
}

\section{ABSTRACT}

Objective: The objective of this systematic review was to state and analyze all the case reports published on extraskeletal extradural Ewing's Sarcoma to date.

Material and Methods: We searched PubMed, MEDLINE, EMBASE, and Google Scholar using the following search term, including Boolean operators AND and OR. We only included published case reports and series about Ewing's Sarcoma that were Extra-skeletal and Extradural. We excluded the intradural EWS cases and those that did not have both components, i.e. extraskeletal and extradural. Conference articles, commentaries, and unpublished articles were also not included. A PRISMA flowchart was also formed.

Results: After the first case of EES in 1969, around 40 case reports and series have been reported, which sheds light on the rarity of this disease. Age of presentation varies from as early as two months, with the oldest report being 49 years of age, and most cases presenting in adolescents and young adults. Spinal Epidural extraskeletal Ewing's sarcoma has been more frequently reported in males. The level of occurrence of the tumor also varies among cases, with cervical, thoracic and lumbar regions being more frequently affected than sacral regions.

Conclusion: Extraskeletal extradural ES is an exceedingly rare anomaly. Multicentric collaborative work is the need of the hour for such orphan illnesses, to optimize treatment paradigms as a single-center is exceedingly unlikely to amass cases.

Keywords: Ewing's Sarcoma, Primitive Neuroectodermal Tumor, Spine, Extradural, Extraskeletal.

Abbreviations: ES: Ewing's Sarcoma. PNET: Primitive Neuroectodermal Tumor. WHO: World Health Organization. EES: Extraskeletal Ewing's Sarcoma. PAS: Periodic acid-Schiff. CT: Computerized Tomography. $\mathrm{MRI}$ : Resonance Imaging.

Corresponding Author: Kashif Ali Sultan

Department of Neurosurgery, Allama Iqbal Medical College,

Jinnah Hospital, Lahore - Pakistan

Email: sultankashif11@gmail.com
Date of Submission: 31-08-2021

Date of Revision: 15-09-2021

Date of Acceptance: 17-09-2021

Date of Online Publishing: 30-09-2021

Date of Print: 30-09-2021

DOI: $10.36552 /$ pjns.v25i3.593 


\section{INTRODUCTION}

Primary spinal extradural Ewing's sarcoma (ES), also known as primitive neuroectodermal tumor (PNET), is a rare, heterogeneous group of malignant tumors of childhood and early adulthood. According to The World Health Organization (WHO) classification, PNET is an undifferentiated round cell tumor that arises from primitive neuroepithelial cells. Depending on the presentation site, it can be a centrally located or peripheral PNET. ${ }^{1}$ Spinal Epidural PNET/peripheral primitive neuroectodermal tumors ( $\mathrm{PPNET}$ ) have an incidence of $<1 \%$ of primary spinal tumors. ${ }^{2}$ Extraosseous Ewing's sarcoma commonly presents in soft tissues and bones of the lower extremity, paravertebral, and retroperitoneal regions. ${ }^{3}$ Tefft et al. in 1969, were the first to describe the extraosseous form of Ewing's sarcoma, and called it 'extraskeletal Ewing's sarcoma (EES). ${ }^{4}$

\section{MATERIALS AND METHODS}

\section{Search Strategy}

We searched PubMed, MEDLINE, EMBASE, and Google Scholar using the following search term, including Boolean operators AND and OR: (("epidural space"[MeSH Terms]) OR (epidural[All Fields]) OR (extradural[All Fields])) AND ((extraskeletal[All Fields]) OR (extraosseous[All Fields])) AND (("sarcoma, ewing"[MeSH Terms]) OR (Ewing sarcoma[All Fields]) OR ("EWS"[All Fields]) OR (("askin tumor"[Supplementary Concept]) OR (askin tumor[All Fields]) OR ("neuroectodermal tumors, primitive, peripheral"[MeSH Terms]) OR (peripheral primitive neuroectodermal tumors [All Fields]).

\section{Inclusion Criteria}

We only included published case reports and series about Ewing's Sarcoma that were extraskeletal and extradural.

\section{Exclusion Criteria}

We excluded the intradural EWS cases and those that did not have both components, i.e. extraskeletal and extradural. Conference articles, commentaries, and unpublished articles were also not included. Study selection criteria are summarized in Table 1.

Table 1: Inclusion and Exclusion Criteria.

\begin{tabular}{ll} 
Inclusion Criteria & Exclusion Criteria \\
\hline Published Articles & $\begin{array}{l}\text { Unpublished articles } \\
\text { Case Reports }\end{array}$ \\
$\begin{array}{l}\text { Conference articles and } \\
\text { commentaries }\end{array}$ \\
$\begin{array}{l}\text { Articles related to Extraskeletal } \\
\text { and Extradural EWS }\end{array}$ & $\begin{array}{l}\text { Articles related to } \\
\text { Intradural EWS }\end{array}$
\end{tabular}

\section{Data Extraction and Analysis}

The current results and conclusions presented in the case reports were extracted and tabulated systematically. The PRISMA flowchart for our search strategy is shown in Figure 1.

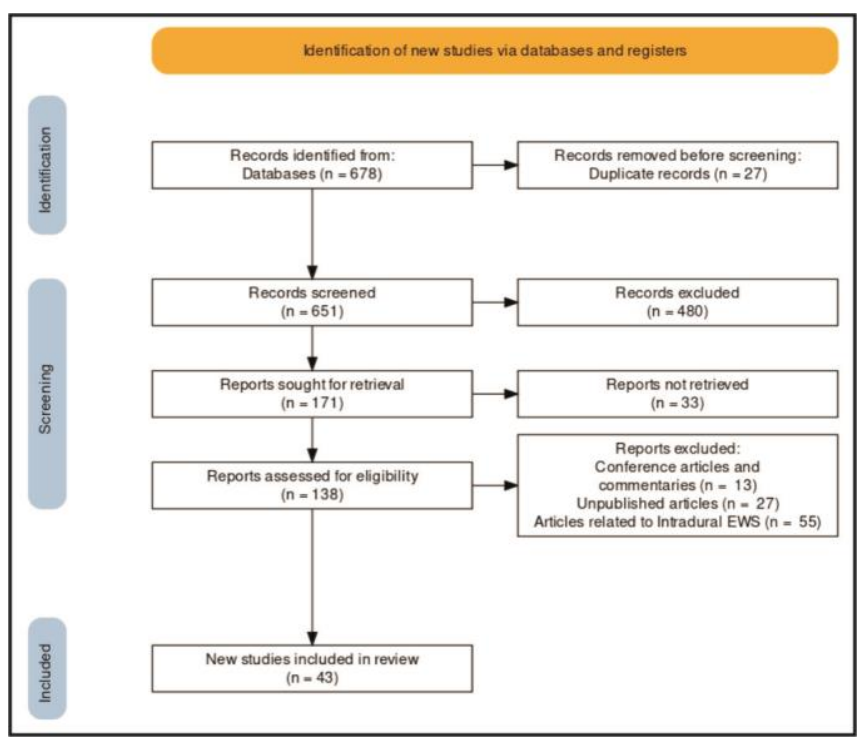

Figure 1: PRISMA Flowchart. 


\section{RESULTS}

\section{Demography}

After the first case of EES in 1969, around 40 case reports and series have been reported, which sheds light on the rarity of this disease. Age of presentation varies from as early as two months, with the oldest case being 49 years of age, with most cases presenting in adolescents and young adults. Spinal Epidural extraskeletal Ewing's sarcoma has been more frequently reported in males.

\section{Location}

The level of occurrence of the tumor also varies among cases, with cervical, thoracic and lumbar regions being more frequently affected than sacral regions. Isolated segment involvement is rare, and the tumor is usually seen extending into adjacent segments.

\section{Treatment and Management}

The usual treatment regimen consists of partial or complete resection, depending on the tumor's extent, site, and size, along with radiotherapy and chemotherapy. Follow-ups were conducted in all reported cases with outcomes ranging from "no evidence of disease" and "alive with disease" to "dead of disease". Cases not receiving any adjuvant therapy died only a few months after presentation. A complete therapy decreased the chance of local recurrence and metastasis in most cases.

\section{Diagnostic Criteria}

Standard diagnostics consist of physical and neurological examinations and radiography. A whole-body bone scan with 99Tc was conducted in some cases to identify any existing metastatic lesions. After the biopsy, light, and electron microscopic examinations were conducted to confirm the diagnosis.

Periodic acid-Schiff (PAS) stain was positive in all reported cases. Immunohistochemistry and genetic testing were also utilized in some cases. Recent cases of extraskeletal Ewing's sarcoma are found to be positive for CD99 (MIC 2). However, the data for cases from before 2000 is not available. Positivity for Vimentin, Synaptophysin, S-100, and other markers varied among the cases and cannot be relied upon as diagnostic. The $\mathrm{t}(11: 22)$ translocation is also associated with extraskeletal Ewing's sarcoma; however, this was not studied in most of the reported cases. Details of all reported cases are given in Table 2.

Table 2: Reported cases of primary spinal extradural extraskeletal Ewing's sarcoma.

\begin{tabular}{|c|c|c|c|c|c|c|c|c|}
\hline $\begin{array}{l}\text { Author (Year of } \\
\text { Publication) }\end{array}$ & $\begin{array}{l}\text { Age } \\
\text { (Years) }\end{array}$ & Gender & Level & Resection & $\begin{array}{l}\text { Adjuvant } \\
\text { Treatment }\end{array}$ & CD99 & $t(11: 22)$ & $\begin{array}{l}\text { Outcome } \\
\text { (Months) }\end{array}$ \\
\hline \multirow{4}{*}{ Tefft et al. (1969) ${ }^{4}$} & 6 & $\mathrm{~F}$ & L4 & Complete & $\mathrm{RT}+\mathrm{CT}$ & N/A & N/A & DOD (48) \\
\hline & 8 Months & M & $\mathrm{T} 11-\mathrm{L} 2$ & Partial & $\mathrm{RT}+\mathrm{CT}$ & $\mathrm{N} / \mathrm{A}$ & $\mathrm{N} / \mathrm{A}$ & NED (60) \\
\hline & 2 & M & $\mathrm{C} 3$ & Partial & $\mathrm{RT}+\mathrm{CT}$ & $\mathrm{N} / \mathrm{A}$ & $\mathrm{N} / \mathrm{A}$ & NED (114) \\
\hline & 7 & $\mathrm{~F}$ & $\mathrm{C} 2$ & Partial & $\mathrm{RT}+\mathrm{CT}$ & $\mathrm{N} / \mathrm{A}$ & $\mathrm{N} / \mathrm{A}$ & $\mathrm{DOD}(9)$ \\
\hline \multirow{3}{*}{ Angervall \& Enzinger $(1975)^{5}$} & 17 & $M$ & $\mathrm{~S} 1-\mathrm{S} 2$ & Complete & None & N/A & N/A & DOD (1) \\
\hline & 20 & M & $\mathrm{T} 2-\mathrm{T} 5$ & Partial & $\mathrm{RT}+\mathrm{CT}$ & $\mathrm{N} / \mathrm{A}$ & N/A & DOD (13) \\
\hline & 18 & $\mathrm{~F}$ & L5 & Complete & $\mathrm{RT}+\mathrm{CT}$ & N/A & $\mathrm{N} / \mathrm{A}$ & $\mathrm{DOD}(7)$ \\
\hline \multirow{2}{*}{ Scheithauer \& Egbert $(1978)^{6}$} & 18 & M & L1 & Complete & $\mathrm{RT}+\mathrm{CT}$ & $\mathrm{N} / \mathrm{A}$ & $\mathrm{N} / \mathrm{A}$ & NED (16) \\
\hline & 27 & $\mathrm{~F}$ & $\mathrm{~T} 4-\mathrm{T} 6$ & Complete & $\mathrm{RT}+\mathrm{CT}$ & N/A & $\mathrm{N} / \mathrm{A}$ & NED (120) \\
\hline Mahoney et al. (1978) ${ }^{7}$ & 23 & M & $\mathrm{L} 5-\mathrm{S} 1$ & Partial & $R T+C T$ & N/A & $\mathrm{N} / \mathrm{A}$ & DOD (12) \\
\hline
\end{tabular}




\begin{tabular}{|c|c|c|c|c|c|c|c|c|}
\hline $\begin{array}{l}\text { Author (Year of } \\
\text { Publication) }\end{array}$ & $\begin{array}{l}\text { Age } \\
\text { (Years) }\end{array}$ & Gender & Level & Resection & $\begin{array}{l}\text { Adjuvant } \\
\text { Treatment }\end{array}$ & CD99 & $t(11: 22)$ & $\begin{array}{l}\text { Outcome } \\
\text { (Months) }\end{array}$ \\
\hline Fink \& Meriwether (1979) ${ }^{8}$ & 19 & M & $\mathrm{L} 2-\mathrm{L} 3$ & Partial & $\mathrm{RT}+\mathrm{CT}$ & N/A & N/A & NED (6) \\
\hline Simonati et al. (1981) ${ }^{9}$ & 13 & M & L3 & Complete & $\mathrm{RT}+\mathrm{CT}$ & $\mathrm{N} / \mathrm{A}$ & N/A & NED (15) \\
\hline \multirow{2}{*}{$\mathrm{N}^{\prime}$ Golet et al. $(1982)^{10}$} & 30 & M & $\mathrm{T} 1-\mathrm{T} 3$ & Complete & $\mathrm{RT}+\mathrm{CT}$ & $\mathrm{N} / \mathrm{A}$ & N/A & NED (6) \\
\hline & 47 & $\mathrm{~F}$ & L4 & Complete & $\mathrm{RT}$ & $\mathrm{N} / \mathrm{A}$ & $\mathrm{N} / \mathrm{A}$ & DOD (4) \\
\hline Demeocq et al. (1983) ${ }^{11}$ & 16 & $\mathrm{~F}$ & $\mathrm{~L} 3-\mathrm{L} 4$ & Partial & $\mathrm{CT}$ & $\mathrm{N} / \mathrm{A}$ & $\mathrm{N} / \mathrm{A}$ & $\mathrm{N} / \mathrm{A}$ \\
\hline Kinsella et al. (1983) ${ }^{12}$ & 14 & $\mathrm{~F}$ & $\mathrm{~L} 4-\mathrm{L} 5$ & Complete & $\mathrm{RT}+\mathrm{CT}$ & $\mathrm{N} / \mathrm{A}$ & $\mathrm{N} / \mathrm{A}$ & NED (48) \\
\hline Spaziante et al. (1983) ${ }^{13}$ & 10 & M & $L 4-S 2$ & Partial & $\mathrm{RT}+\mathrm{CT}$ & $\mathrm{N} / \mathrm{A}$ & $\mathrm{N} / \mathrm{A}$ & DOD (16) \\
\hline \multirow{2}{*}{ Asorey et al. (1986) ${ }^{\star}$} & 8 & $\mathrm{~F}$ & N/A & Complete & $\mathrm{RT}+\mathrm{CT}$ & N/A & $\mathrm{N} / \mathrm{A}$ & NED (60) \\
\hline & 10 & $\mathrm{~F}$ & $\mathrm{~N} / \mathrm{A}$ & Complete & $\mathrm{RT}+\mathrm{CT}$ & $\mathrm{N} / \mathrm{A}$ & $\mathrm{N} / \mathrm{A}$ & NED (26) \\
\hline Machin et al. (1986) ${ }^{14}$ & 4 & M & L1 & Complete & None & $\mathrm{N} / \mathrm{A}$ & $\mathrm{N} / \mathrm{A}$ & DOD (5) \\
\hline Sharma et al. (1986) ${ }^{15}$ & 18 & M & $\mathrm{T} 11$ & Partial & $\mathrm{RT}+\mathrm{CT}$ & $\mathrm{N} / \mathrm{A}$ & $\mathrm{N} / \mathrm{A}$ & DOD (42) \\
\hline Ruelle \& Boccardo (1987) ${ }^{16}$ & 17 & M & L3 & Partial & $\mathrm{RT}+\mathrm{CT}$ & N/A & $\mathrm{N} / \mathrm{A}$ & DOD (8) \\
\hline Benmeir et al. (1991) ${ }^{17}$ & 17 & $\mathrm{~F}$ & $\mathrm{~T} 8-\mathrm{T} 10$ & Complete & $\mathrm{RT}+\mathrm{CT}$ & N/A & N/A & NED (6) \\
\hline Kaspers et al. (1981) ${ }^{18}$ & 7 & M & $\mathrm{L} 1-\mathrm{L} 2$ & Partial & $\mathrm{CT}$ & $\mathrm{N} / \mathrm{A}$ & $\mathrm{N} / \mathrm{A}$ & NED (40) \\
\hline Allam\& Sze (1994) ${ }^{19}$ & 15 & $\mathrm{~F}$ & T12- L3 & N/A & $\mathrm{N} / \mathrm{A}$ & N/A & N/A & N/A \\
\hline Christie et al. (1997) ${ }^{20}$ & 36 & $\mathrm{~F}$ & $\mathrm{~L} 2-\mathrm{L} 3$ & Partial & $\mathrm{RT}+\mathrm{CT}$ & N/A & $\mathrm{N} / \mathrm{A}$ & DOD (96) \\
\hline Benesch et al. (1999) ${ }^{21}$ & 2 months & M & $\mathrm{L} 3-\mathrm{S} 1$ & Partial & $\mathrm{RT}+\mathrm{CT}$ & N/A & - & DOD \\
\hline \multirow[t]{2}{*}{ Kennedy et al.(2000) ${ }^{22}$} & 24 & M & $\mathrm{C} 1-\mathrm{C} 5$ & Partial & $\mathrm{RT}+\mathrm{CT}$ & N/A & N/A & NED (13) \\
\hline & 22 & M & $\mathrm{T} 4-\mathrm{T} 5$ & Complete & $R T+C T$ & N/A & N/A & NED (66) \\
\hline \multirow{3}{*}{ Morandi et al. (2001) ${ }^{23}$} & 14 & M & $\mathrm{C} 3-\mathrm{C} 7$ & Partial & $\mathrm{RT}+\mathrm{CT}$ & N/A & $\mathrm{N} / \mathrm{A}$ & DOD (42) \\
\hline & 16 & $\mathrm{~F}$ & $\mathrm{C} 5-\mathrm{C} 7$ & Partial & $\mathrm{RT}+\mathrm{CT}$ & N/A & $\mathrm{N} / \mathrm{A}$ & DOD (54) \\
\hline & 25 & M & $\mathrm{L} 1-\mathrm{S} 2$ & Partial & $\mathrm{CT}$ & N/A & N/A & $\mathrm{DOD}(7)$ \\
\hline \multirow{5}{*}{ Mukhopadhyay et al. $(2001)^{24}$} & 29 & $\mathrm{~F}$ & $\mathrm{C} 3-\mathrm{C} 5$ & Partial & $R T+C T$ & N/A & N/A & NED (30) \\
\hline & 18 & $\mathrm{M}$ & T8 & Partial & $\mathrm{RT}+\mathrm{CT}$ & + & $\mathrm{N} / \mathrm{A}$ & AWD (18) \\
\hline & 22 & M & $\mathrm{L} 5-\mathrm{S} 1$ & Partial & $\mathrm{RT}+\mathrm{CT}$ & + & $\mathrm{N} / \mathrm{A}$ & NED (15) \\
\hline & 31 & M & L3 - L4 & Partial & $\mathrm{RT}+\mathrm{CT}$ & + & N/A & NED (32) \\
\hline & 13 & M & $\mathrm{C} 3-\mathrm{C} 5$ & Partial & $\mathrm{RT}+\mathrm{CT}$ & + & N/A & NED (11) \\
\hline \multirow{2}{*}{ Shin et al. $(2001)^{25}$} & 38 & M & $\mathrm{C} 5-\mathrm{C} 7$ & Partial & $\mathrm{CT}$ & + & $\mathrm{N} / \mathrm{A}$ & AWD (5) \\
\hline & 22 & $\mathrm{~F}$ & $\mathrm{C} 7-\mathrm{T} 1$ & Partial & $\mathrm{CT}$ & + & N/A & NED (48) \\
\hline Kadri et al. (2002) ${ }^{26}$ & 15 & $\mathrm{~F}$ & $\mathrm{~L} 2-\mathrm{L} 3$ & Partial & $\mathrm{RT}+\mathrm{CT}$ & + & N/A & NED (7) \\
\hline Gandhi et al. (2003) ${ }^{27}$ & 33 & M & $\mathrm{T} 5-\mathrm{T} 9$ & Complete & $\mathrm{RT}+\mathrm{CT}$ & $\mathrm{N} / \mathrm{A}$ & N/A & NED (3) \\
\hline Harimaya et al. (2003) ${ }^{28}$ & 12 & $\mathrm{~F}$ & $\mathrm{~T} 1-\mathrm{T} 3$ & Partial & $\begin{array}{l}\mathrm{RT}+\mathrm{CT}+ \\
\mathrm{PBSCT}\end{array}$ & N/A & N/A & DOD (32) \\
\hline Kogawa et al. (2004) ${ }^{29}$ & 7 & $\mathrm{~F}$ & $\mathrm{C} 2-\mathrm{C} 4$ & Complete & $\begin{array}{l}\mathrm{RT}+\mathrm{CT}+ \\
\mathrm{PBSCT}\end{array}$ & + & $\mathrm{N} / \mathrm{A}$ & NED (60) \\
\hline
\end{tabular}




\begin{tabular}{|c|c|c|c|c|c|c|c|c|}
\hline $\begin{array}{l}\text { Author (Year of } \\
\text { Publication) }\end{array}$ & $\begin{array}{l}\text { Age } \\
\text { (Years) }\end{array}$ & Gender & Level & Resection & $\begin{array}{l}\text { Adjuvant } \\
\text { Treatment }\end{array}$ & CD99 & $t(11: 22)$ & $\begin{array}{l}\text { Outcome } \\
\text { (Months) }\end{array}$ \\
\hline Siami-Namini et al. $(2005)^{30}$ & 15 & $\mathrm{~F}$ & $\mathrm{~T} 3-\mathrm{T} 7$ & Partial & N/A & + & + & $\mathrm{N} / \mathrm{A}$ \\
\hline Athanassiadou et al.(2006) ${ }^{31}$ & 13 & M & T9 & Partial & $\mathrm{RT}+\mathrm{CT}$ & + & + & AWD (9) \\
\hline Isefuku et al. $(2006)^{32}$ & 20 & M & $\mathrm{L} 5-\mathrm{S} 1$ & Complete & $\mathrm{CT}$ & + & + & DOD (15) \\
\hline Bozkurt et al. $(2007)^{33}$ & 28 & M & $\mathrm{C} 3-\mathrm{C} 5$ & Complete & $\mathrm{RT}+\mathrm{QT}$ & N/A & N/A & NED (18) \\
\hline Erkutlu et al. $(2007)^{34}$ & 7 & M & $\mathrm{C} 5-\mathrm{T} 1$ & Complete & $\mathrm{RT}+\mathrm{QT}$ & + & N/A & NED (108) \\
\hline Lakhdar et al. $(2007)^{35}$ & 24 & $\mathrm{~F}$ & $\mathrm{C} 6-\mathrm{T} 1$ & Complete & $\mathrm{RT}+\mathrm{CT}$ & N/A & N/A & NED (12) \\
\hline Ozturk et al. $(2007)^{36}$ & 18 & M & $\mathrm{C} 6-\mathrm{T} 1$ & Complete & CT & + & N/A & NED (13) \\
\hline Hsieh et al. (2008) ${ }^{37}$ & 12 & M & $\mathrm{T} 7-\mathrm{T} 9$ & Complete & $\mathrm{RT}+\mathrm{CT}$ & + & N/A & NED (20) \\
\hline Dogan et al. $(2009)^{38}$ & 13 & M & $\mathrm{T} 11-\mathrm{L} 1$ & Complete & $\mathrm{RT}+\mathrm{CT}$ & + & N/A & NED (10) \\
\hline Avcu et al. (2010) ${ }^{39}$ & 30 & M & L5 & Complete & $\mathrm{RT}+\mathrm{CT}$ & N/A & N/A & $\mathrm{N} / \mathrm{A}$ \\
\hline Yasuda et al. (2011) ${ }^{40}$ & 37 & $\mathrm{~F}$ & T8 - T9 & Partial & $\mathrm{RT}+\mathrm{CT}$ & + & N/A & DOD (22) \\
\hline Saeedinia et al.(2012) ${ }^{41}$ & 44 & $\mathrm{~F}$ & $\mathrm{~S} 1-\mathrm{S} 3$ & Complete & RT & + & N/A & NED (18) \\
\hline Garcia Moreno et al.(2014) ${ }^{2}$ & 45 & $\mathrm{~F}$ & $\mathrm{C} 6-\mathrm{T} 3$ & Partial & $\mathrm{RT}+\mathrm{CT}$ & + & + & NED (7) \\
\hline Eloqayli (2017) ${ }^{42}$ & 49 & M & $\mathrm{C} 6-\mathrm{T} 2$ & Partial & $\mathrm{RT}+\mathrm{CT}$ & + & N/A & NED (12) \\
\hline Kutty et al. (2017) ${ }^{43}$ & 12 & $\mathrm{~F}$ & $\mathrm{C} 2-\mathrm{C} 4$ & Complete & $\mathrm{RT}+\mathrm{CT}$ & + & N/A & NED (16) \\
\hline Bedoya et al. (2019) ${ }^{44}$ & 9 & $\mathrm{~F}$ & $\mathrm{~T} 2$ & Complete & $\mathrm{RT}+\mathrm{CT}$ & + & N/A & DOD (36) \\
\hline
\end{tabular}

KEY: M: Male; F: Female; C: Cervical; T: Thoracic; L: Lumbar; S: Sacral; RT: Radiotherapy; CT: Chemotherapy; PBSCT: Peripheral Blood Stem Cell Transplantation; DOD: Dead of Disease; NED: No Evidence of Disease; AWD: Alive with Disease; N/A: Not Available; +: Positive Result; -: Negative Result. *: The Complete Original Article Could Not be Found on the Internet; Hence the Data of This Study Was Taken from García-Moreno et al. ${ }^{2}$

\section{DISCUSSION}

James Ewing was the first one to describe Ewing's sarcoma (ES) in $1921 .^{3}$ He referred to it as diffuse endothelioma, which was later coined to ES by Oberling in 1928. In 1973, Hart and Earle introduced the term primary PNET, meaning a tumor arising from central neuraxis, having a single progenitor cell and containing more than $90-95 \%$ undifferentiated cells. Ewing's sarcomas that arise from soft tissues are named Extraskeletal Ewing Sarcoma (EES). The first case of EES was reported by Tefft et al. in 1969. ${ }^{4}$

\section{Demography}

The peak incidence of EES patients is seen around 20 years of age, with an approximate range from
10 to 30 years. According to Yasuda et al, male predominance is seen in spinal extradural EES, with the male-female ratio turning out to be 1.5:1. $\mathrm{He}$ also reviewed $30 \mathrm{EES}$ cases and found out that the mean age of this disease's presentation is 18.8 years, with $73 \%$ of all the reported cases being between 10 to 20 years old. ${ }^{40}$ This disease is so rare that the frequency in the western part of the world is reported to be $1-3$ per million. ${ }^{45}$

\section{Location}

The most common sites of this tumor are the buttocks, upper and lower extremities, thoracic wall, and retroperitoneal space. However, some cases report these tumors in the larynx, small intestine, kidney, skin, vagina, and paravertebral area. 


\section{Clinical Presentation}

The most common presenting complaint of the patient is chronic back pain, which occurs due to compression of spinal cord and nerve roots, followed by upper and lower limb muscle weakness. ${ }^{41}$ Autonomic dysfunction of the urinary bladder is also a common late presentation. If the mass becomes metastatic, the most commonly involved organ is the lung. In contrast to the spinal EES, the intracranial location of these tumors causes headaches and visual disturbances in the patients. Severe complications may involve intracranial hemorrhages.

\section{Radiological Findings}

Computerized Tomography (CT) and Magnetic Resonance Imaging (MRI) is usually employed for diagnosis. It is usually seen as a wellcircumscribed, extramedullary, intradural, or extradural mass that may extend through intervertebral foramina and extend into the paraspinal soft tissue. ${ }^{46}$ Dumb-bell-shaped tumors with foraminal widening, ${ }^{47}$ and scalloping of bones ${ }^{25}$ are some additional findings that can be seen. These tumors can also metastasize. CT scan of the thorax is more useful in showing soft tissue mass with or without pleural and rib damage. ${ }^{48}$ On a non-enhanced CT scan, a welldefined hypodense mass is seen displacing the thecal sac and contrast-enhancement shows a heterogeneous tumor. EES may present as a biconvex lesion on radiology, resembling an extradural hematoma. Therefore, if a trauma patient arrives at the hospital with minor and multiple lesions, extradural EES should be one of the differential diagnoses. T-1 weighted imaging may show variable isointense and hypointense signals, while T-2 weighted may show isointense and hypertense on unenhanced MRI. Postcontrast MRI usually reveals a heterogeneous color enhancement within the mass suspected of Ewing's Sarcoma. ${ }^{49}$

\section{Histopathological Findings}

On light microscopy, poorly differentiated, small round cells are seen, which have mitotic figures, a high nucleus to cytoplasm ratio, and scanty cytoplasm. The typical arrangement may be in the form of nests, sheets, lobules, or occasionally rosettes. EES are hence classed as small round cell tumors and can be misdiagnosed as lymphoma or a small cell carcinoma of the lung. However, most of the lymphomas are LCA positive too. On Electron microscopy, scanty cytoplasmic organelles are seen, accompanied by growth cones suggestive of glial cell differentiation. ${ }^{48}$

\section{Immunohistochemistry}

Immunohistochemical analysis is needed for further classification and definitive diagnosis of EES. About $95 \%$ of the EES cases show CD99 (MIC2) positivity. Although a very suggestive marker, it is not specific. ${ }^{50}$ In addition; synovial sarcomas also show CD99 positivity in some cases. Therefore, during lab analysis, in addition to CD-99, other tumor markers that are usually ordered include CD-34, CD-20, CD-10, Tdt, and others, to rule out other potential causes of tumors.

\section{FISH Analysis}

The $t(11 ; 22)$ (q24;q12) translocation is a chromosomal aberration seen in $90 \%$ of cases of ES and is used for confirmation. ${ }^{51}$ It results in the formation of the EWS-FLI1 fusion gene. ${ }^{52}$ ERG, ETV1, EIAF, and FEV variant translocations are also observed in a few cases. The fusion protein EWSFLI1 possesses oncogenic properties. Lab studies performed on immunocompromised mice show that its expression can hasten tumorigenesis of murine NIH 3T3 cells. ${ }^{53}$ Repression of this fusion gene using antisense constructs has shown to 
decrease cell growth in-vitro as well as tumor growth in-vivo in human cell lines. ${ }^{54}$ However, the function of the EWS-FLI-1 fusion protein is highly dependent on the cell in context. Identifying the genes involved in the initiating phase of Ewing's Sarcoma development may evade approaches using established heterologous cell lines and cells derived from late-stage Ewing's Sarcomas. To have a clear understanding of the pathogenesis of this disease, the mechanism of initiation of the fusion protein and involvement of the type of target cell should be determined. ${ }^{55}$

\section{Treatment and Management}

Surgery is the mainstay of treatment if long-term survival is intended. Depending on the adherence and accessibility of the tumor, biopsy, nearcomplete resection, or complete resection can be performed. ${ }^{56}$ Laminectomy is generally advocated. Radiotherapy and chemotherapy are the proposed adjuvant therapies. Frequently used chemotherapeutic drugs include Vincristine, Cyclophosphamide, Cisplatin, and Ifosfamide. The 5 -year survival rate of EES even after the adjuvant therapy ranges from $38 \%{ }^{57}$ to $67 \% .{ }^{58}$

\section{Prognosis}

Primary intraspinal EES/pPNET is an aggressive malignant tumor that leads to mortality within two years of diagnosis in almost half of the patients. Age is an important determinant of the prognosis of the tumor. At both extremes, that means the mortality rate increases as the age group gets younger and as the age group gets older. However, no specific pattern can be seen when it comes to the gender of the patient. Surgical resection, whether subtotal or total, combined with adjuvant therapies including chemotherapy and radiotherapy significantly improves the outcome of the patients.

\section{CONCLUSION}

Extraskeletal Ewing's Sarcoma is an exceedingly rare anmaly. Gross total resection and adjuvant therapy are very important for the long-term survival of such patients. Proper education and techniques should be utilized to ensure early detection and treatment. Metacentric collaborative work is the need of the hour for such orphan illnesses, to optimize treatment paradigms as a single-center is exceedingly unlikely to amass cases.

\section{REFERENCES}

1. Ellis J, Rothrock R, Moise G, McCormick P, Tanji K, Canoll $P$ et al. Primitive neuroectodermal tumors of the spine: a comprehensive review with illustrative clinical cases. Neurosurgical Focus, 2011; 30 (1): E1.

2. García-Moreno R, Bernal-García L, Pineda-Palomo $M$, Botana-Fernández $M$, Gilete-Tejero I, Cabezudo-Artero J. Sarcoma de Ewing extraesquelético epidural. Caso clínico y revisión de la literatura. Neurocirugía. 2015; 26 (3): 151 156.

3. Choudhury K, Sharma S, Kothari R, Majumder A. Primary extraosseous intracranial Ewing's sarcoma: Case report and literature review. Indian Journal of Medical and Paediatric Oncology, 2011; 32 (02): 118-121.

4. Tefft M, Vawter G, Mitus A. Paravertebral "Round Cell" Tumors in Children. Radiology, 1969; 92 (7): 1501-1509.

5. Angervall L, Enzinger F. Extraskeletal neoplasm resembling Ewing's sarcoma. Cancer, 1975; 36 (1): 240-251.

6. Scheithauer B, Egbert B. Ewing's sarcoma of the spinal epidural space: report of two cases. Journal of Neurology, Neurosurgery \& Psychiatry, 1978; 41 (11): 1031-1035.

7. Mahoney JP, Ballinger Jr. WE, Alexander RW. Socalled extraskeletal Ewing's sarcoma. Report of a case with ultrastructural analysis. Am J Clin Pathol. 1978; 70: 926-31. 
8. Fink LH, Meriwether MW. Primary epidural Ewing's sarcoma presenting as a lumbar disc protrusion. Case report. J Neurosurg. 1979; 51: 120-3.

9. Simonati A, Vio M, lannucci AM, Bricolo A, Rizzuto N. Lumbar epidural Ewing sarcoma. Light and electron microscopic investigation. J Neurol. 1981; 225: 67-72.

10. N'Golet A, Pasquier B, Pasquier D, Lachard A, Couderc P. Extraskeletal Ewing's sarcoma of the epidural space. A report of two new cases with literature review. Arch Anat Cytol Pathol. 1982; 30: 10-3.

11. Demeocq F, Fonck $Y$, Legros $M$, Chazal J, Plagne R, Dauplat J. Extraskeletal Ewing's sarcoma. Anatomoclinical study of a new case. Pediatrie. 1983; 38: 475-8.

12. Kinsella T, Triche T, Dickman P, Costa J, Tepper J, Glaubiger D. Extraskeletal Ewing's sarcoma: results of combined modality treatment. Journal of Clinical Oncology, 1983; 1 (8): 489-495.

13. Spaziante $R$, de Divitiis $E$, Giamundo $A$, Gambardella A, Di Prisco B. Ewing's sarcoma arising primarily in the spinal epidural space: fifth case report. Neurosurgery, 1983; 12: 337-41.

14. Machin M, Garcia-Sagredo M, Munoz A, Lozano C, Aparicio M. 18q-syndrome and extraskeletal Ewing's sarcoma. J Med Genet, 1987; 24: 426-8.

15. Sharma BS, Khosla VK, Banerjee AK. Primary spinal epidural Ewing's sarcoma. Clin Neurol Neurosurg. 1986; 88: 299-302.

16. Ruelle A, Boccardo M. Epidural extraskeletal Ewing's sarcoma simulating a herniated disk. Clinical case. Riv Neurol. 1986; 56: 183-8.

17. Ben-Meir P, Picard E, Sagi A, Greber B, Hertzanu $Y$, Tiberin $P$, et al. Epidural extraskeletal Ewing's sarcoma: the tenth case. Rev Neurol (Paris), 1989; 145: 324-7.

18. Kaspers GJ, Kamphorst W, van de Graaff $M$, van Alphen HA, Veerman AJ. Primary spinal epidural extraosseous Ewing's sarcoma. Cancer, 1991; 68: 648-54.

19. Allam K, Sze G. MR of primary extraosseous Ewing sarcoma. AJNR Am J Neuroradiol. 1994; 15: 305-7.

20. Christie D, Bilous A, Carr P. Diagnostic difficulties in extraosseous Ewing's sarcoma: A proposal for diagnostic criteria. Australasian Radiology, 1997;
41 (1): 22-28.

21. Benesch $M$, Urban $C$, Lackner $H$, Kerbl $R$, Schwinger W, Beham-Schmid $C$ et al. Atypical extraosseous Ewing sarcoma of the spinal canal with bone marrow involvement in a two-month-old boy. Medical and Pediatric Oncology, 1999; 32 (6): 471473.

22. Kennedy JG, Eustace S, Caulfield R, Fennelly DJ, Hurson B, O'Rourke KS. Extraskeletal Ewing's sarcoma: a case report and review of the literature. Spine, 2000; 25: 1996-9.

23. Morandi X, Riffaud L, Haegelen C, Lancien G, Kerbrat $P$, Guegan Y. Sarcome d'Ewing extraosseux épidural rachidien [Extraosseous Ewing's sarcoma of the spinal epidural space]. Neurochirurgie, 2001; 47 (1): 38-44.

24. Mukhopadhyay P, Gairola M, Sharma M, Thulkar S, Julka $P$, Rath $G$. Primary spinal epidural extraosseous Ewing's sarcoma: report of five cases and literature review. Australas Radiol. 2001; 45: 372-9.

25. Shin JH, Lee HK, Rhim SC, Cho KJ, Choi CG, Suh DC. Spinal epidural extraskeletal Ewing sarcoma: MR findings in two cases. AJNR Am J Neuroradiol. 2001; 22 (4): 795-8.

26. Kadri PA, Mello PM, Olivera JG, Braga FM. Primary lumbar epidural Ewing's sarcoma: case report. Arq Neuropsiquiatr. 2002; 60: 145-9.

27. Gandhi D, Goyal M, Belanger E, Modha A, Wolffe J, Miller W. Primary epidural Ewing's sarcoma: case report and review of literature. Can Assoc Radiol J. 2003; 54: 109-13.

28. Harimaya K, Oda Y, Matsuda S, Tanaka K, Chuman $\mathrm{H}$, Iwamoto $\mathrm{Y}$. Primitive Neuroectodermal Tumor and Extraskeletal Ewing Sarcoma Arising Primarily Around the Spinal Column. Spine, 2003; 28 (19): E408-E412.

29. Kogawa $M$, Asazuma $T$, Iso $K$, Koike $Y$, Domoto $H$, Aida $S$, et al. Primary cervical spinal epidural Extraosseous Ewing's sarcoma. Acta Neurochir (Wien), 2004; 146: 1051-3.

30. Siami-Namini K, Shuey-Drake R, Wilson D, Francel $P$, Perry A, Fung KM. A 15-year-old female with progressive myelopathy. Brain Pathol. 2005; 15: 265-7.

31. Athanassiadou F, Tragiannidis A, Kourti $M$, Papageorgiou T, Kotoula V, Kontopoulos V, et al. Spinal epidural extraskeletal Ewing sarcoma in an 
adolescent boy: a case report. Pediatr Hematol Oncol. 2006; 23: 263-7.

32. Isefuku S, Seki M, Tajino T, Hakozaki M, Asano S, Hojo $\mathrm{H}$ et al. Ewing's Sarcoma in the Spinal Nerve Root: A Case Report and Review of the Literature. The Tohoku Journal of Experimental Medicine, 2006; 209 (4): 369-377.

33. Bozkurt G, Ayhan S, Turk C, Akbay A, Soylemezoglu $F$, Palaoglu S. Primary extraosseous Ewing sarcoma of the cervical epidural space. Journal of Neurosurgery: Spine, 2007; 6 (2): 192.

34. Erkutlu I, Buyukhatipoglu H, Alptekin M, Ozsarac C, Buyukbese I, Gok A. Primary Spinal Epidural Extraosseous Ewing's Sarcoma Mimicking a Spinal Abscess. Pediatric Hematology and Oncology, 2007; 24 (7): 537-542.

35. Lakhdar F, Gana R, Laghmari M, Moufid F, Maaqili $R$, Bellakhdar F. Sarcome d'Ewing épidural cervical infecté (à propos d'un cas). Journal of Neuroradiology, 2008; 35 (1): 51-55.

36. Ozturk E, Mutlu H, Sonmez G, Vardar Aker F, Cinar Basekim C, Kizilkaya E. Spinal epidural extraskeletal Ewing sarcoma. Journal of Neuroradiology, 2007; 34 (1): 63-67.

37. Hsieh CT, Chiang YH, Tsai WC, Sheu LF, Liu MY. Primary spinal epidural Ewing sarcoma: a case report and review of the literature. Turk J Pediatr. 2008; 50 (3): 282-286.

38. Dogan S, Leković G, Theodore N, Horn E, Eschbacher J, Rekate H. Primary thoracolumbar Ewing's sarcoma presenting as isolated epidural mass. The Spine Journal, 2009; 9 (1): e9-e14.

39. Avcu $S$, Özcan $H$, İzmirli $M$, Lemmerling $M$. RETRACTED ARTICLE: $C T$ and $M R$ findings in a neuroforaminal extraskeletal Ewing sarcoma mimicking benign nerve sheath tumor. Irish Journal of Medical Science, 2010; 181 (1): 123-125.

40. Yasuda T. Extraskeletal Ewing's sarcoma of the thoracic epidural space: Case report and review of the literature. Oncology Reports, 2011

41. Amirjamshidi A, Saeedinia $S$, Alimohammadi $M$, Nouri $M$, Moradi $H$. Primary spinal extradural Ewing's sarcoma (primitive neuroectodermal tumor): Report of a case and meta-analysis of the reported cases in the literature. Surgical Neurology International, 2012; 3 (1): 55.

42. Eloqayli H. Adult primary cervical extra-osseous Ewing's sarcoma: A case report and short literature review. Int J Surg Case Rep. 2017; 41: 83-85.

43. Kutty $R$, Peethambaran A, Sunilkumar B, Balachandran Nair K, Korde $P$, Jain S. Ewing Sarcoma of the Cervical Epidural Space Presenting with Tetraplegia: Case Report and Review of Literature. World Neurosurgery, 2017; 107: 1046.e9-1046.e15.

44. Bedoya GA, Bello N, Moná $L$, Velásquez $K$, Sandoval J, Castro-Alvarez JF. Sarcoma de Ewing extraóseo en la columna dorsal con compresión medular al momento del diagnóstico: Reporte de un caso [Primary extra-osseous Ewing sarcoma of the dorsal spine with spinal cord compression at diagnosis: Case report]. Arch Argent Pediatr. 2019; 117 (1): e41-e46.

45. Singleton $S$, Koerner $C$. Lenticular lesions: Not always an epidural hematoma. Pediatric Emergency Care, 2001; 17 (4): 252-254.

46. Duan X, Ban X, Liu B, Zhong X, Guo R, Zhang F et al. Intraspinal primitive neuroectodermal tumor: Imaging findings in six cases. European Journal of Radiology, 2011; 80 (2): 426-431.

47. Bailly R, Bosselut R, Zucman J, Cormier F, Delattre $O$, Roussel $M$ et al. DNA-binding and transcriptional activation properties of the EWSFLI-1 fusion protein resulting from the $t(11 ; 22)$ translocation in Ewing sarcoma. Molecular and Cellular Biology, 1994; 14 (5): 3230-3241.

48. Patil A, Gupta P, Iratwar S. Primary spinal extradural extraosseous primitive neuroectodermal tumor/Ewing's sarcoma: A critical analysis and review. Asian J Neurosurg. 2021; 16 (2): 276.

49. Jing $Z$, Wen-yi L, Jian-li L, Jun-lin $Z$, Chi D. The imaging features of meningeal Ewing sarcoma/peripheral primitive neuroectodermal tumours (pPNETs). The British Journal of Radiology, 2014; 87 (1041): 20130631.

50. Folpe A, Goldblum J, Rubin B, Shehata B, Liu W, Dei Tos $A$ et al. Morphologic and Immunophenotypic Diversity in Ewing Family Tumors. American Journal of Surgical Pathology, 2005; 29 (8): 1025-1033.

51. Delattre O, Zucman J, Plougastel B, Desmaze C, Melot T, Peter $M$ et al. Gene fusion with an ETS DNA-binding domain caused by chromosome translocation in human tumours. Nature, 1992; 359 (6391): 162-165.

52. Janknecht R. EWS-ETS oncoproteins: The linchpins 
of Ewing tumors. Gene, 2005; 363: 1-14.

53. Thompson A, Teitell M, Arvand A, Denny C. Divergent Ewing's sarcoma EWS/ETS fusions confer a common tumorigenic phenotype on NIH3T3 cells. Oncogene. 1999; 18 (40): 5506-5513.

54. Kovar $H$, Aryee DN, Jug $G$, et al. EWS/FLI-1 antagonists induce growth inhibition of Ewing tumor cells in vitro. Cell growth Differ Mol Biol J Am Assoc Cancer Res. 1996; 7 (4): 429-437.

55. Riggi $N$, Suvà $M$, Suvà $D$, Cironi $L$, Provero $P$, Tercier $S$ et al. EWS-FLI-1 Expression Triggers a Ewing's Sarcoma Initiation Program in Primary Human Mesenchymal Stem Cells. Cancer Research, 2008; 68 (7): 2176-2185.
56. Eghbal K, Dehghanian A, Ghaffarpasand F. Lumbosacral epidural primitive neuroectodermal tumor (pnet); case report and literature review. Turkish Neurosurgery, 2017.

57. Shimada H, Newton W, Soule E, Qualman S, Aoyama C, Maurer $H$. Pathologic features of extraosseous Ewing's sarcoma: A report from the intergroup rhabdomyosarcoma study. Human Pathology, 1988; 19 (4): 442-453.

58. Rud N, Reiman H, Pritchard D, Frassica F, Smithson W. Extraosseous Ewing's sarcoma. A study of 42 cases. Cancer, 1989; 64 (7): 1548-1553.

\section{Additional Information}

Disclosures: Authors report no conflict of interest.

Conflicts of Interest: In compliance with the ICMJE uniform disclosure form, all authors declare the following:

Financial Relationships: All authors have declared that they have no financial relationships at present or within the previous three years with any organizations that might have an interest in the submitted work.

Other Relationships: All authors have declared that there are no other relationships or activities that could appear to have influenced the submitted work.

Funding Disclosure: No funding was available for this study.

\section{AUTHORS CONTRIBUTIONS}

\begin{tabular}{|l|l|l|}
\hline Sr.\# & Author's Full Name & Intellectual Contribution to Paper in Terms of: \\
\hline 1. & Kashif Ali Sultan & Study design and methodology. \\
\hline 2. & Biah Mustafa & Analysis of data, paper writing, referencing. \\
\hline 3. & Mohammad Ashraf & Data collection and calculations. \\
\hline 4. & Minaam Farooq & Analysis of data and paper writing. \\
\hline 5. & Naveed Ashraf & Analysis of data and interpretation of results. \\
\hline 6. & Mukarram Farooq & Literature review. \\
\hline 7. & Musa Ali Rizvi & Literature review. \\
\hline 8. & Waaiz Ali Wajid & Literature review. \\
\hline
\end{tabular}

